\title{
MEMBANGUN KERUKUNAN MASYARAKAT BEDA AGAMA MELALUI INTERAKSI DAN KOMUNIKASI HARMONI DI DESA TALANG BENUANG PROVINSI BENGKULU
}

\author{
Ujang Mahadi \\ Fakultas Ushuluddin, Adab dan Dakwah IAIN Bengkulu
}

\begin{abstract}
ABSTRAK
Penelitian ini mencoba mengangkat pola interaksi masyarakat beda agama di Desa Talang Benuang Kecamatan Air Periukan Kabupaten Seluma Provinsi Bengkulu. Paradigma dalam penelitian ini adalah kualitatif dengan menggunakan pendekatan sosiologi dan interaksionisme simbolik. Pengumpulan data dilakukan dengan teknik wawancara, observasi dan studi dokumentasi. Hasil penelitian menunjukkan bahwa kerukunan hidup masyarakat beda agama di Desa Talang Benuang Kecamatan Air Periukan Kabupaten Seluma Provinsi Bengkulu terbangun melalui interaksi dan komunikasi harmoni yang saling menghargai, saling menghormati, saling memberikan toleransi dan tidak menyinggung masalah agama dalam kehidupan masyarakat. Faktor lain yang mendukung adalah: pertama, adanya kesadaran tinggi dari masyarakat akan pentingnya kerukunan hidup beragama yang ditanamkan sejak kecil secara turun temurun oleh pendahulunya; kedua, tumbuhnya jiwa nasionalisme dalam kehidupan masyarakat; dan ketiga, adanya ikatan kekerabatan yang dihasilkan dari pernikahan yang sebelumnya beda agama.
\end{abstract}

Kata-kata kunci: Kerukunan, beda agama, interaksi dan komunikasi.

\section{CONSTRUCTING A COHESIVE DIFFERENT RELIGION COMMUNITY THROUGH INTERACTION AND COMMUNICATION HARMONY IN THE TALANG BENUANG VILLAGE BENGKULU PROVINCE}

\begin{abstract}
This study tries to raise the issue on the interaction patterns of different religion communities in Talang Benuang village, Seluma County, Air Periukan District, Bengkulu province. Paradigm used in this study is qualitativewith sociology and symbolic interactionism approach. The data was collected by using interviews, observations and documentation. The results showsthat the harmony of people from different religions in Talang Benuang village, Seluma County, Air Periukan District, Bengkulu province has been developed through interaction and concord communication of mutual respect, tolerance and by not touching religious subject in their daily life.Another supporting factorsare: first, anincrease of awareness on the importance of religious harmony by introduce them since their childhood for generations. Second, the growth of nationalism in the communities, and Third, the existence of kinship as a result from previous interfaith marriages.
\end{abstract}

Keywords: Tolerance, interfaith, interaction and communication.

Korespondensi: Dr. Ujang Mahadi, M.Si., Fakultas Ushuluddin, Adab dan Dakwah IAIN Bengkulu, Jl. Pagar Dewa Air Sebakul Bengkulu 38613,Email: mahadi4kdzhnh@yahoo.com 


\section{PENDAHULUAN}

Kitab suci al-Qur'an, dalam beberapa ayat menyinggung masalah kemajemukan atau pluralitas, seperti pada surat al-Hujurat ayat 13 dan surat ar-Rum ayat 32. Pluralitas agama di era globalisasi menjadi karakteristik dari bangsa Indonesia yang heterogen. Sehingga tak bisa dipungkiri, pluralitas agama ini memiliki potensi dan peran sangat besar dalam proses integrasi dan pembangunan. Di samping itu, pluralitas agama ini juga mengandung potensi terjadinya konflik, disintegrasi bangsa, ketika melihat masing-masing agama memiliki klaim kebenaran absolut dan muatan emosi keagamaan yang menjadi dasar interaksi primer (Yewangoe, 2009: 26).

Konflik atas dasar perbedaan agama bisa disebabkan baik oleh ajaran agama itu sendiri, kualitas moral - spiritual penganutnya, maupun latar belakang budaya, seperti kultur patriarkal atau ikatan primordial yang masih kuat. Secara struktural perbedaan agama tersebut berkaitan erat dengan rasa insecurity dalam bidang sosial, ekonomi, politik, dan budaya (Masykur, 2006).

Potensi konflik atau disintegrasi ini sangat dalam akibatnya, sangat luas dan besar implikasinya, dan dapat menelan ongkos sosial, politik dan ekonomi yang teramat mahal. Konflik yang dilatarbelakangi oleh faktor agama, lebih berbahaya dibandingkan dengan latar belakang lain. Hal ini disebabkan mengingat watak agama itu sendiri yang tidak mengenal batas sosiologis, demografis, maupun geografis. Di samping itu, agama sangat berpengaruh dalam totalitas kepribadian, serta penghayatan pada tingkat lapisan awam (Masykur, 2006).

Kenyataan juga memperlihatkan bahwa agama merupakan suatu sistem yang total. Menurut Emile Durkheim dalam karyanya yang terkenal Les Formes Elementaires de la vie Religieuse seperti dikutip Koentjaraningrat, bahwa ada empat unsur pokok dalam agama, yaitu emosi keagamaan, sistem kepercayaan, sistem upacara, dan komunitas keagamaan (Koentjaraningrat, 1978: 136-137). Emosi keagamaan menyebabkan manusia menjadi religius. Sistem kepercayaan mengandung keyakinan serta bayangan - bayangan manusia tentang sifat-sifat Tuhan serta tentang wujud dari alam gaib. Sistem upacara religius bertujuan mencari hubungan manusia dengan Tuhan, dewa-dewa atau mahluk-mahluk halus yang mendiami alam gaib, dan kelompok-kelompok religius atau kesatuan-kesatuan sosial yang menganut sistem kepercayaan dan melakukan sistem upacara -upacara religius (Masykur, 2006).

Dalam hubungan antar komunitas dan emosi keagamaan, akan terbentuk ikatan primer dan solidaritas kelompok, mengingat emosi keagamaan merupakan dasar ikatan primer dalam komunitas masyarakat dan sumber dari sentimen kemasyarakatan, dimana kesadaran tentang hubungan itu menjadi paling kuat dan paling mudah disinggung dan dilukai. Sehingga, umat beragama gampang disulut bagi timbulnya konflik mengatasnamakan agama (Masykur, 2006).

Agama adalah praktik, keyakinan, dan pengalaman yang berhubungan dengan sistemkepercayaan. Levinmengatakan bahwa agama mengandung klaim kebenaran yang bersifat universal (Levin, 2001: 10). Hal ini memungkinkan terjadi ambiguitas dalam interpretasi menurut tingkat pemahaman, penghayatan, dan moralitas-spiritualitas penganutnya. Fenomena ini tampak dalam penggunaan konsep-konsep atau simbol-simbol agama untuk orientasi tertentu ketika melibatkan emosi keagamaan penganutnya. Untuk itu, menghindari konflik atau mewujudkan kerukunan umat beragama merupakan nilai universal. Dengan nilai ini, semua manusia melalui agamanya diharapkan dapat hidup rukun, berdampingan secara damai, saling menghormati, saling toleransi, dan bekerjasama dalam menangani persoalan kemanusiaan (Masykur, 2006).

Kerukunan antar umat beragama menjadi sesuatu yang sangat penting, mendasar dan merupakan satu-satunya pilihan. Namun yang perlu di garis bawahi adalah bahwa kerukunan yang mesti dikembangkan bukanlah kerukunan yang artifisial atau verbalis-semantik, tetapi kerukunan yang otentik, dinamis, realistis yang bertolak serta merupakan refleksi dari ajaran agama yang dianut. Kerukunan seperti ini dilandasi kesadaran bahwa walaupun berbeda agama tetapi memiliki kesadaran tanggung jawab dan keterpanggilan untuk memperjuangkan kesejahteraan bagi semua orang (Sairin, 2006: xi).

Sebagaimana dikemukakan Menteri Agama Suryadharma Ali, upaya membangun kerukunan 
umat beragama itu masih jauh selesai. Oleh karena itu, dalam upaya untuk memperkokoh kerukunan umat beragama, Kementrian Agama sangat berkepentingan akan hadirnya sebuah payung hukum atau regulasi yang mengatur masalah ini, sehingga menjadi rujukan bagi siapa saja dalam merekonstruksi kerukunan umat beragama (Anam, 2012: 6).

Kehidupan beragama yang dinamis dengan terciptanya kerukunan umat beragama melalui interaksi dan komunikasi harmoni, saling menghormati dan menghargai serta membangun budaya gotong royong dan kebersamaan, tentu saja akan membawa manfaat yang sangat besar dalam hidup bermasyarakat, berbangsa, dan bernegara.

Interaksi sosial mutlak dilakukan dalam masyarakat. Tidak ada masyarakat yang didalamnya tidak terjadi interaksi. Interaksi sosial merupakan suatu kewajaran, bahkan merupakan kebutuhan pokok bagi kehidupan setiap insan. Interaksi sosial merupakan bagian yang integral dari kehidupan dalam masyarakat.

Tulisan ini merupakan hasil penelitian tentang pola interaksi masyarakat beda agama di Desa Talang BenuangKecamatan Air Periukan Kabupaten Seluma Provinsi Bengkulu. Pluralitas masyarakatnya bukan saja dari sisi agama tetapi juga suku dan bahasa mereka beragam. Masyarakatnya terdiri dari enam suku, yaitu: suku Serawai, suku Bali, suku Jawa, sukuPadang, suku Rejang dan suku Batak. Mayoritas penduduknya adalah suku Serawai dan beragama Islam, selebihnya beragama Hindu dan Kristen.

Keunikan dan menariknya, masyarakat yang plural dengan berbagai perbedaan suku, bahasa dan agama mereka bisa hidup berdampingan, rukun - damai, saling menghormati dan menghargai satu sama lain, terbangun budaya gotong royong dan kebersamaan, bahkan masyarakat yang mayoritas beragama Islam dipimpin oleh Kepala Desa yang beragama Hindu.

Dari latar belakang penelitian di atas, dapat dirumuskan masalahnya sebagai berikut: (1). Bagaimana pola interaksi masyarakat beda agama di Desa Talang Benuang Kecamatan Air Periukan Kabupaten Seluma?; dan (2). Apa saja faktor pendukung pola interaksi masyarakat beda agama di Desa Talang Benuang Kecamatan Air Periukan Kabupaten Seluma?

\section{METODE PENELITIAN}

Paradigma penelitian yang digunakan dalam penelitian ini adalah kualitatif. Metode kualitatif sebagaimana dikatakan Taylor dan Bogdan sebagai prosedur penelitian yang menghasilkan data deskriptif berupa kata-kata tertulis atau lisan dari orang atau gejala yang diamati (dalam Vardiansyah, 2005: 69). Pendekatan kualitatif-interpretif diarahkan pada latar gejala secara holistik (utuh menyeluruh) dan alamiah sehingga tidak mengisolasikan gejala ke dalam variabel. Namun, mengkaji objeknya sesuai latar alamiahnya.

\section{HASIL DAN PEMBAHASAN}

Sejak ditetapkannya Desa Talang Benuang sebagai salah satu desa trans lokal (38 tahun yang lalu) untuk menampung warga transmigrasi berasal dari daerah Bali yang notabene beragama Hindu, maka kemajemukan dan pluralitas agama tidak dapat dihindari, karena masyarakat asli pada umumnya beragama Islam.

Menurut Nyoman Rado (tokoh masyarakat Hindu), semenjak Ia menetap di Talang Benuang (tahun 1978) belum pernah terjadi konflik dengan isu SARA, apalagi kekerasan anarkis sampai jatuhnya korban jiwa. Begitu juga dengan pernyataan yang disampaikan oleh Endang Subandi (tokoh masyarakat Islam)

Proses interaksi dan komunikasi dengan warga pendatang yang beragama Hindu terjalin begitu akrab dikarenakan ada titik temu yang positif, dalam artian warga pribumi bisa menerima warga pendatang dengan semangat kebersamaan dan warga pendatang bisa menyesuaikan diri dengan kebiasaan, adat dan agama yang dianut oleh pribumi. Kondisi seperti inilah yang diharapkan semua warga masyarakat Talang Benuang, bisa mewujudkan interaksi yang positif.

Interaksi masyarakat beda agama di Desa Talang Benuang, khususnya masyarakat yang beragama Islam dengan masyarakat yang beragama Hindu berlangsung secara sirkuler timbal balik. Interaksi dibingkai dengan saling menghargai, menghormati, toleransi dan tidak 
menyinggung/melibatkan agama. Hal ini dapat digambarkan oleh diagram 1 di bawah.

Dari diagram 1 dapat dipahami bahwa masyarakat pribumi yang mayoritas beragama Islam dengan masyarakat Bali yang beragama Hindu dalam menjalankan interaksi dan komunikasi, kedua belah pihak yang berbeda agama memberikan sikap dan perlakuan yang sama, yakni senantiasa mengedepankan sikap menghargai, saling menghormati, toleransi dan tidak menyinggung atau melibatkan persoalan agama.

Sejak lahir manusia mempunyai naluri untuk hidup bergaul dan berdampingan dengan manusia lainnya. Naluri ini merupakan salah satu kebutuhan asasi manusia, karena manusia tidak bisa memenuhi kebutuhannya sendiri untuk bertahan hidup tanpa bantuan orang lain. Keterikatan tersebut menunjukkan bahwa manusia adalah makhluk sosial, yang secara sosiologis membutuhkan interaksi dan hubungan timbal balik yang satu dengan yang lainnya saling mempengaruhi. Interaksi sosial merupakan hubungan sosial yang dinamis, cair dan mengalir yang di dalamnya membawa muatan nilai, budaya, etika, dan bahkan agama.

Masyarakat beda agama di Desa Talang Benuang memiliki pola interaksi yang unik sebagai perekat dalam menciptakan kerukunan dan harmonisasi kehidupan dengan saling menghormati dan menghargai. Pola interaksi mereka dapat di- gambarkan oleh diagram 2.

Dari diagram 2 dapat dijelaskan bahwa masyarakat Muslim dan masyarakat Hindu memiliki konsep dan penerapan yang sama dalam membangun interaksi, yaitu sebagai berikut: (1). Masyarakat Muslim dan masyarakat Hindu, kedua belah pihak sama-sama memiliki pemahaman tentang pentingnya penanaman nilai kerukunan hidup beragama, dan ini sudah ditanamkan sejak kecil dan berlangsung turun - temurun.

Hal ini dapat dilihat dan dibuktikan ketika anak-anak mereka bermain kelereng bersama, ke kebun bersama dan ke sekolah bersama. Jika terjadi keributan mereka segera menyelesaikan dan mendamaikannya, tanpa ada menyinggung masalah agama; (2). Nilai-nilai nasionalisme dalam masyarakat dijunjung tinggi dan tumbuh dengan baik, sehingga terjalin keharmonisan dan kebersamaan. Dampak positif lainnya dari nilai-nilai nasionalisme berupa kesadaran masyarakat dalam kegiatan gotong royong, siskamling, musyawarah desa, aktif dan berkontribusi dalam kegiatan sosial dan memperingati hari besar nasional; dan (3). Ikatan kekerabatan yang dihasilkan dari perkawinan juga menjadi bagian penting dari pola interaksi masyarakat beda agama. Ketika ada keluarga Muslim yang akan menikah dengan keluarga Hindu atau sebaliknya, mereka melakukan musyawarah untuk mengambil kesepakatan tentang status agama yang

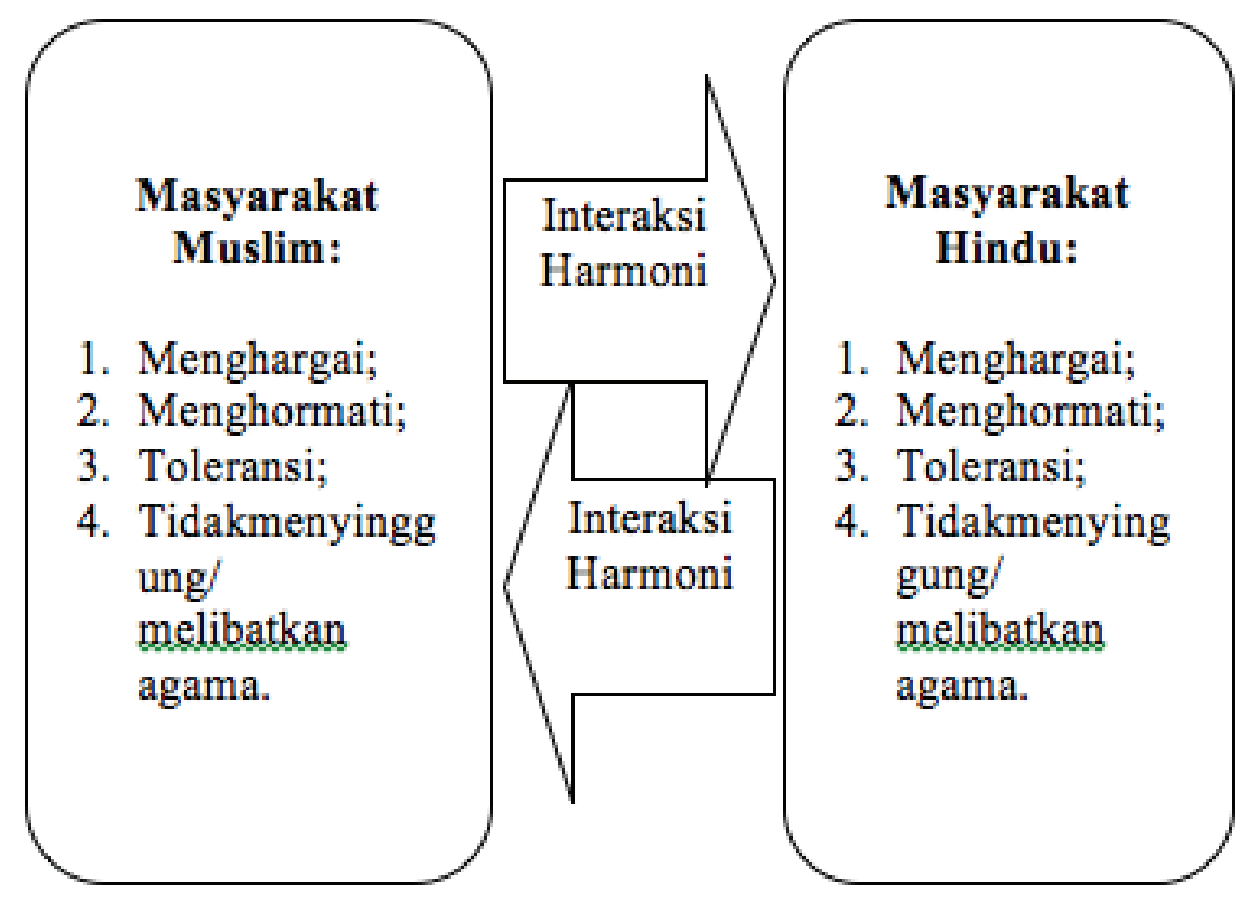

Diagram 1 Bingkai Interaksi Masyarakat Beda Agama 


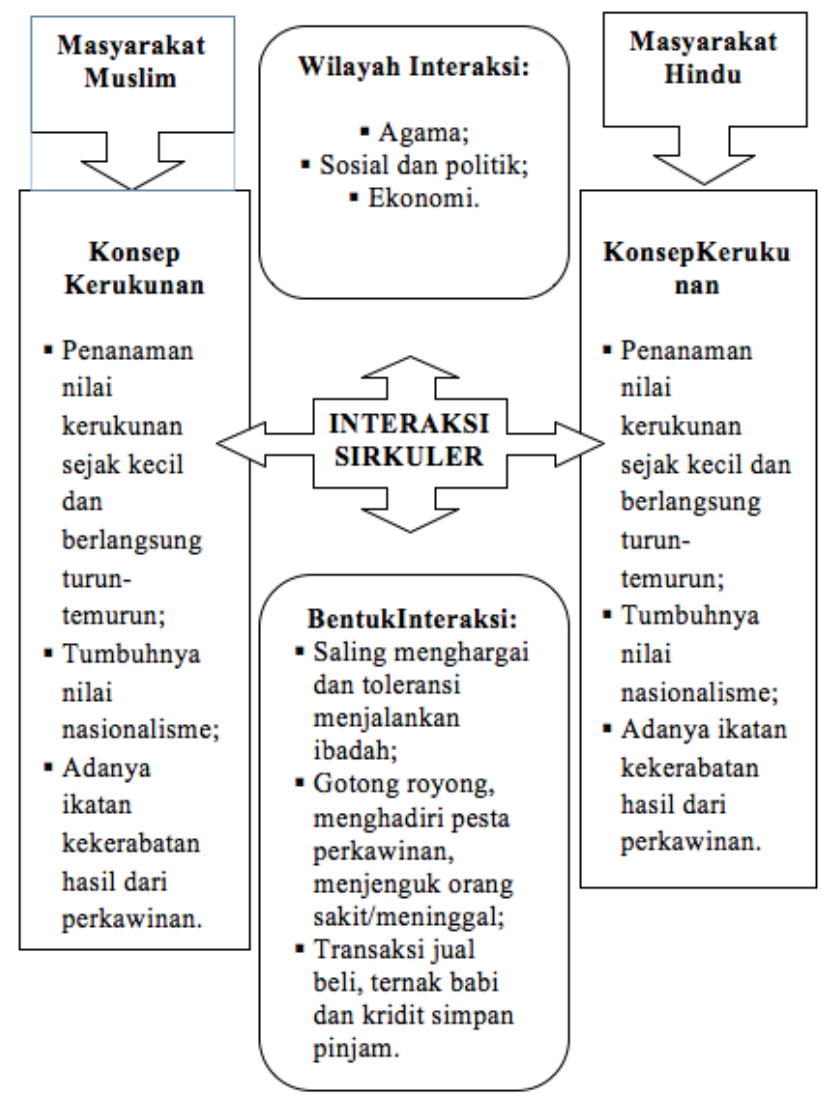

\section{Diagram 2 Pola Interaksi Masyarakat Beda Agama}

akan dianut. Ikatan pernikahan inilah yang juga menjadi salah satu pendukung terjadinya interaksi yang positif antar masyarakat beda agama di Desa Talang Benuang.

Interaksi masyarakat beda agama di Desa Talang Benuang pada wilayah agama berlangsung harmonis dan terbangun hubungan yang saling toleran serta menghormati agama dan ibadah yang mereka lakukan. Melalui observasi dan wawancara mendalam diketahui bahwa bentuk interaksi masyarakat beda agama di Desa Talang Benuang pada wilayah agama dapat dilihat ketika masyarakat Muslim merayakan hari besar Islam, mereka tetap menghargai Kepala Desa yang beragama Hindu dengan menyampaikan undangan untuk menghadiri. Kepala Desa, karena rasa tanggung jawab dan toleransinya, mengutus perangkat desa yang beragama Islam untuk mewakilinya menghadiri acara dimaksud.

Pada bulan suci Ramadhan, saat umat Islam melakukan kewajiban ibadah puasa, masyarakat Hindu sangat toleransi kepada umat Islam yang sedang menjalankan ibadah puasa dan amalan lainnya. Mereka menasihati anak-anaknya untuk tidak makan dan minum ketika di sekolah. Begitu juga pada malam hari, aktivitas warga di
RT 11 dan RT 12 yang dihuni masyarakat Bali tidak mengadakan acara-acara yang bersifat gebyar dan keramaian.

Kehidupan sosial masyarakat Desa Talang Benuang berjalan sangat luwes dan fleksibel. Luwes dalam arti bahwa proses interaksi yang berlangsung di tengah masyarakat belum atau tidak pernah terjadi konflik/ketegangan yang berarti. Fleksibel artinya, interaksi dalam masyarakat berlangsung tanpa ada diskriminasi dari kalangan mana pun dapat berbaur di tengah masyarakat. Made Sujana (Kepala Desa beragama Hindu) menjelaskan bahwa

Proses interaksi masyarakat tergambar dalam pergaulan sehari-hari pada anggota masyarakat yang sangat cair dan membaur, tidak ada sentimen agama dan tendensi kesukuan yang mencolok, kami semua diikat dengan sebuah pemahaman kebangsaan yang tinggi, kami ini warga masyarakat Indonesia.

Berkenaan dengan pemilihan Kepala Desa yang merupakan ranah sosial dan politik, Suprih Eko (Sekretaris Desa beragama Islam) menjelaskan 
Proses demokrasi dan politik lokal di Desa Talang Benuang berjalan denagn baik. Ia memaparkan ketika pemilihan Kepala Desa di tahun 2008 silam sangat terlihat kecerdasan warga. Dimana ada 2 calon yang muncul dan mereka berbeda agama, yaitu Made Sujana (asal Bali beragama Hindu) dan lawannya Akhir Mansyah (pribumi beragama Islam). Secara logika, calon yang beragama Islam pasti menang jika dilihat dari jumlah penduduk yang mayoritasnya Islam $(79,9 \%)$ dibandingkan dengan penduduk yang beragama Hindu (19,9 \%). Tetapi fakta dan realita yang terjadi adalah calon dari agama minoritas Made Sujana beragama Hindu berhasil mendapatkan suara terbanyak dalam pemilihan itu. Ini menunjukkan kedewasaan dalam proses politik lokal, bahwa calon pemimpin yang mereka pilih adalah yang memiliki kemampuan dan kompetensi, bukan masalah agama atau suku.

Kemenangan Made Sujana (kaum migran yang beragama Hindu) menjadi Kepala Desa karena Ia memiliki jiwa sosial dan kepedulian yang tinggi dalam kehidupan bermasyarakat, dirinya sangat akrab dan dekat dengan semua warga dan itu terealisasi jauh sebelum pemilihan Kepala Desa. Bukan itu saja, Ia juga sebagai sosok yang sangat akomodatif, ini ditunjukkan dengan komposisi perangkat desa yang melibatkan semua elemen. Dalam menyelesaikan permasalahan yang terjadi di masyarakat Ia senantiasa mengedepankan semangat musyawarah dan kekeluargaan. Dalman (Ketua RT. 8 Desa Talang Benuang) menjelaskan

Sebagai Kepala Desa, dirinya membangun dan menumbuhkan sikap kebersamaan dalam masyarakat tanpa ada diskriminasi. Ini bisa dilihat ketika ada kegiatan-kegiatan desa seperti kerja bakti setiap minggu dan perayaan hari-hari nasional. Setiap 17 Agustus kami gotong royong membuat gapura dan hiasan lainya, dan kami pun memeriahkannya dengan pesta rakyat yaitu panjat pinang, dan acaranya bergantian di setiap RT, tapi tahun ini tidak digelar karena umat Muslim lagi puasa.
Berkaitan dengan masalah musibah kematian, orang sakit dan acara perkawinan, mereka sangat toleransi dan saling mengunjungi, seperti yang dikatakan I Made Kanten (Ketua RT. 12 Talang Benuang)

Dalam hal musibah kematian dan musibah sakit masyarakat saling berkunjung, walaupun beda agama. Begitu juga pada acara pesta perkawinan mereka saling mengundang dan menghadiri. Ia mencontohkan, ketika warga Bali mengadakan resepsi perkawinan, warga muslim diundang dan mereka menghadiri acara tersebut tanpa ada keraguan dalam hal makanan, karena tuan rumah telah menyiapkan hidangan (katering khusus) untuk undangan yang beragama Islam, tempatnya tersendiri dan mereka dilayanai oleh sesama orang Islam.

Kegiatan ekonomi di Desa Talang Benuang tidak membedakan agama penjual atau pembeli. Pada masing-masing RT terdapat warung sebagai mata pencaharian warga, tetapi pembelinya tidak saja warga RT tersebut, tetapi juga warga RT yang lainnya. Warung milik warga beragama Hindu juga sering dibeli oleh warga yang beragama Islam, begitu juga sebaliknya. Seperti dikatakan seorang warga yang tidak mau disebutkan namanya Saya sering membeli rokok di warung orang Bali yang beragama Hindu saat mau ke kebun, karena jalan ke kebun saya melewati warungnya.

Berkenaan dengan jajanan dan makanan olahan, pedagang warga Bali yang namanya juga tidak mau disebutkan mengatakan bahwa Anak-anak jarang membelinya dan kami maklum, tetapi untuk jajanan dan makanan kemasan anak-anak mereka (beragama Islam) biasa membelinya, seperti jajanan sneck.

Usaha ekonomi lain yang ditekuni warga Bali adalah usaha ternak babi. Meski begitu, masyarakat Bali memahami keberadaan ternak babi yang mereka pelihara dekat masyarakat Islam. Mereka membuat kandang khusus agar babi peliharaannya tidak bebas atau liar. Ternak babi hanya dipelihara di 2 RT tempat masyarakat Bali bermukim.

Sikap toleransi yang tinggi ditunjukkan oleh warga muslim, walaupun dalam ajaran Islam babi adalah hewan yang diharamkan, tetapi us- 
aha ternak tersebut menjadi mata pencaharian utama bagi masyarakat Bali, maka orang Islam bisa memakluminya. Kegiatan ekonomi lainnya berupa program Kredit Usaha Tani yang menyediakan dana bergulir. Dalam pelaksanaannya tidak ada diskriminasi bagi peminjam/ penerima, dana tersebut didistribusikan sesuai secara profesional dan proporsional.

Harmonisasi interaksi masyarakat beda agama tidak terlepas dari proses saling memahami dan menghormati agama masing-masing yang mereka anut. Kerukunan umat beragama dalam masyarakat harus dibentuk dan diciptakan bersama, dan ini melalui proses yang berkesinambungan.

Disadari, bahwa salah satu pemicu munculnya konflik antar umat beragama adalah tidak adanya kesadaran untuk memahami dan memberikan toleransi terhadap orang lain yang berbeda agama. Dalam konteks inilah pentingnya dikembangkan kesadaran akan pemahaman dan toletransi beragama, yaitu kemauan dan kemampuan untuk menghargai agama lain serta mengaktualisasikannya dalam kehidupan sehari-hari dengan bersikap saling menghormati dan memberikan kebebasan setiap pemeluk agama menjalankan ajarannya.

Dari perspektif interaksionisme simbolik, kehidupan komunitas masyarakat beda agama dalam berinteraksi sarat dengan nilai dan simbol. Begitu juga dengan proses interaksi masyarakat beda agama di Desa Talang Benuang, mereka berusaha memahami agama, budaya dan simbol yang berlangsung dan mewarnai interaksi diantara mereka. Kesadaran masing-masing pihak untuk menghadirkan kerukunan dan toleran terbangun dengan interkasi dan komunikasi yang efektif. Berlandaskan pada pola interaksi dan komunikasi yang efektif, kerukunan, toleransi dan kebersamaan terpelihara dengan baik dalam pergaulan hidup antar warga masyarakat yang berbeda agama. Dengan demikian, kerukunan dan harmonisasi hidup beragama pada dasarnya sebuah pengakuan adanya kebebasan masyarakat dalam memeluk agama yang diyakini sepanjang tidak mengganggu aktivitas agama lain. Interaksi antar umat bergama menjadi bagian penting yang harus diperhatikan agar kerukunan dan toleransi beragama dapat tercapai dan kehidupan yang harmoni ditengah masyarakat berbeda agama dapat terwujud. Ker- ukunan dan harmonisasi kehidupan inilah yang sebenarnya terbangun pada masyarakat beda agama di Desa Talang Benuang sehingga tidak ada konflik dan permusuhan.

\section{SIMPULAN}

Berdasarkan pemaparan, pembahasan dan analisis yang dilakukan pada bab sebelumnya, maka dapat ditarik simpulan sebagai berikut: (1). Pola interaksi masyarakat beda agama di Desa Talang Benuang Kecamatan Air Periukan Kabupaten Seluma terbangun secara harmoni. Interaksi tersebut terjalin melalui berbagai kegiatan sosial kemasyarakatan seperti gotong royong, kelompok tani, kredit simpan pinjam, pesta perkawinan, musibah kematian dan berbagai kegiatan hari besar nasional. Selain itu, harmonisasi dalam masyarakat terbangun karena mereka saling menghargai, saling menghormati, saling memberikan toleransi dan tidak menyinggung masalah agama dalam kehidupan masyarakat; dan (2). Terbangunnya pola interaksi masyarakat beda agama di Desa Talang Benuang Kecamatan Air Periukan Kabupaten Seluma karena didukung oleh beberafa faktor, yaitu: pertama, adanya kesadaran yang tinggi dari masyarakat akan pentingnya kerukunan hidup beragama, dan ini ditanamkan sejak kecil secara turun temurun oleh pendahulunya; kedua, tumbuhnya jiwa nasionalisme dalam kehidupan masyarakat; dan ketiga, adanya ikatan kekerabatan yang dihasilkan dari pernikahan yang sebelumnya beda agama.

Ada dua saran yang direkomendasikan dalam laporan hasil penelitian ini, yaitu saran akademis dan saran praktis, sebagai berikut:

Saran akademis yang perlu ditekankan dari hasil penelitian ini adalah sebagai berikut: (1). Masih banyak aspek lain yang dapat dikaji berkaitan dengan penelitian "Pola Interaksi Masyarakat Beda Agama" dengan menggunakan pendekatan yang berbeda, seperti: pendekatan psikologi, dramaturgi dan pendekatan yang lainnya; dan (2). Penelitian tentang "Pola Interaksi Masyarakat Beda Agama" masih perlu dilakukan dengan melihat permasalahan yang lain, misalnya: aspek pemerintahan, budaya dan sebagainya.

Saran praktis yang dapat disampaikan dari hasil penelitian ini adalah sebagai berikut: (1). Kepada masyarakat yang plural dari segi agama, 
kiranya dapat menjadikan Desa Talang Benuang sebagai cermin dan contoh pola interaksi masyarakat beda agama yang menjunjung tinggi kerukunan hidup dan toleransi beragama; dan (2). Perlunya Pemerintah Daerah memberikan perhatian dan penghargaan (reward) kepada masyarakat Desa Talang Benuang yang telah mewujudkan harmonisasi dan kerukunan hidup.

Semoga tulisan ini menjadi inspirasi segar dan mengedukasi pembaca dalam membangun serta menjunjung tinggi kerukunan hidup dan toleransi beragama di tengah kehidupan masyarakat yang plural. Insya Allah.

\section{DAFTAR PUSTAKA}

Ahmadi, A. (2002). Psikologi sosial. Jakarta: Rineka Cipta.

Anam, S. (2012, April). Merekonstruksi kerukunan yang hakiki. Majalah Ikhlas Beramal [Ed. 74]

Light, D., Keller, S., \& Calhoun, C. (1989). Sociology. McGraw-Hill.

Durkheim, E. (2010). Suicid: A study in sosiology. New York: Free Press.
Koentjaraningrat. (1978). Kebudyaaan, mentalitet dan pembangunan.Jakarta: Gramedia.

Levin, J. (2001). God, faith, and health exploring the spirituality-healing connection. New York: John Wiley \& Son, Inc.

Masykur. (2006). Pola komunikasi antar umat beragama: studi atas dialog umat islam dan kristen di kota cilegon banten. Diakses dari www.ditpertais.net/annualconference/ancon06/makalah/

Sairin, W. (2006). Kerukunan umat beragama pilar utama kerukunan bangsa: butir-butir pikiran. Jakarta: Gunung Mulia.

Susiyanto. (2006). Solidaritas sosial cina muslim dan non - muslim dan faktor - faktor yang mempengaruhinya. Jurnal Penelitian Humaniora [Edisi Khusus], p.94.

Taneko, S. B. (1984). Struktur dan proses sosial: suatu pengantar sosiologi pembangunan. Jakarta: Rajawali.

Vardiansyah, D. (2005). Filsafat ilmu komunikasi suatu pengantar. Indonesia: Indeks Kelompok Gramedia.

Yewangoe, A. A. (2009). Agama dan kerukunan. Jakarta: Gunung Mulia. 